\title{
The Role of Urban Landscape Planning in Neighborhood Physical Reconstruction (Case Study: District 4 Area 11)
}

\author{
M. DOOST HOSSEINI ${ }^{1}$ and M. RAHIMI ${ }^{2 *}$ \\ 'MSA, Department of Urban Planning, Shahre Qods Science and Research Branch, \\ Islamic Azad University, Tehran, Iran. \\ ${ }^{2 *}$ Department of Urban Planning, Shahre Qods Branch, \\ Islamic Azad University, Tehran, Iran. \\ http://dx.doi.org/10.12944/CWE.9.2.16
}

(Received: April 05, 2014; Accepted: June 10, 2014)

\begin{abstract}
Old context, as a complex network of relationships left from previous generations, despite great changes over the last 50 years, yet could not be compatible with the existing conditions of urbanization. The transformation of the socio - economic and political alignment of the present century, in compliance with international trends in developed countries has resulted in the modernization process, creating new spaces in old tissue is physical relations with its past practice. To achieve to overall objective of sustainable development, the main urban areas, especially in vulnerable tissues in studied area as a set in which all the cultural and historical values were underlying, anatomical restoration using urban landscape planning, environment Juicy aesthetically pleasing and healthy. A landscape that deposits in the mind and causes the joy. Evaluation and enhancement of public spaces as places for social meetings and allowing people to interact with the full participation of people in urban management direction has great importance. In this study, assessing public participation in urban management and their attitude towards their environment was carried out using questionnaire. The results showed that the high percentages of people were agree with involving in the affairs of their town, but had no clear view about it. This issue itself showed the importance and necessity of planning for education and cultural programs necessitates for urban management. In this study, with assessing public participation in urban management and their attitude towards their environment, and revolt were studied using questionnaire.
\end{abstract}

Key words: Planning, Urban landscape, Spatial analysis, Participation, Physical rehabilitation.

\section{INTRODUCTION}

City is alive, dynamic and in growing. Cities are growing with several factors associated with an increased population and develop with more important factors including resources. The population growth of cities and urban areas require new structural elements, tailored to the needs of the Iranian urban population in recent decades because of industrialization and modernity with nostalgia modeling of Western society. This phenomenon can be seen as a more acute in metropolitan Tehran. With all-round development of human beings in modern human life, the way of and procedures has changed (Ahmadi, 1997; 2004).
This is especially can be visible in parts of Tehran that we called it as a central contextual, historical, old, problematic from different aspects of physical, infrastructural, urban common sense.

This part has tissues that prepare traditional needs of inhabitants not by fits and new needs of today's citizens to live in a beautiful, healthy and clean city, clean fitting with different needs of social, cultural and economical for urban society (John and Matlak, 2003; Quinn, 2003).

The traditional life requires its special tools, urban spaces, and their body is shaped accordingly. With progress, increasing prosperity and the 
emergence of new needs, new jobs in the service of modern tools, spaces and other traditional buildings are not responsive no longer and space needs are not the cause of this and the next body type to suit the lifestyle, incompatible applications and thus creating a distinct perspective to the landscape and other parts of the city (Ahmadi, 1997; Astrvfsky, 1992).

\section{MATERIALS AND METHODS}

This study is an applied and analytic research. Understanding the problems and offering constructive solutions based on the findings of other scholars and using their knowledge, basic research, and its application to better organize the subject, field methods including direct observation and taking photos, regulation questionnaire (survey) from population by sampling, interviews of scholars, teachers, and citizens have been used.

\section{Importance of survey}

Traditional life needs its special tools and urban spaces and their physics have been shaped based on them. With developing and increasing facilities and creating new jobs for city services, traditional spaces and buildings are not responsive no longer and incompatible applications causes consequently common sense to distinguish faces from other parts of the city.

Such textures generally around the city first foci and in relation to it begins to take shape. This section of town between the level of urbanization transition from slow to rapid urbanization was shaped and is not so much of history and new. Even the spatial contour space is between new and historical context.

Tissues consisting of low and dense area buildings without architectural value, urbanization principles laws and without any aesthetic value have been formed in recent decades and their buildings value will diminish gradually. Despite of having architectural value supplying aesthetic aspects without any abandoned restoration will be destroyed gradually and their pretty faces gone.

Principles of rehabilitation, renovation, reconstruction, and repairing the city

Reconstruction in English is to renovation of the building. The purpose of renewal, is rebuilding an old building or any other object, after its wear. However, reconstruction means restructuring or reorganization that reflects the breadth and depth of its activities. While the concept of the words, rebuilding or renewal, does not content such breadth and depth.

The central part of the city due to its inherent complications face with several problems. So, their problem is multi-dimensional issue that can arise in any particular way. Therefore, to solve their problems often various actions and programs arise that each of them focuses on particular aspect. Common terms and concepts, such as rehabilitation, modernization, reconstruction, resuscitation, repair, restoration, prosperity part, the mental part, cleansing, protection, and the like, all reflect the diversity and complexity of the organization of urban space and urban areas, especially in central cities.

According to performed studies, it can be concluded that a dimensional approach to the problems of urban centers are not so successful. Today, it is further recommended that, due to the characteristics and problems of a city, comprehensive, multidisciplinary and coordinated formulation and implementation should be done. Based on the comprehensive reorganization plan for city center diverse factors including the following should be done:

1. Improvement: increasing quality of life in cultural, psychological, and environmental aspects

2. Reconstruction: the reestablishment of old tissues and building new tissues to fit the new form in a new land and restoration of old buildings;

3. Protection: To prevent the degradation of the physical, economic and social;

4. Identity: enhanced features and attractions of each city to suit with the particular characteristics of the geographic environment especially with its cultural construct (Fig 1).

Study of the experiences of a few countries in the improvement and renovation of old texture iran Remediation activities in Iran in the form of modern style and formally opened in 1931 with the 
construction od space fields, constructed belt around many large cities, destroying unused neighborhoods, non-reversible damage, forcing people to beautifying the buildings, development of some passages in the old quarters of the cities, and so began. (Lari, 1991).

A few years before the outbreak of World War II, the country of Iran asked to help of experts from foreign countries to intervene again in the context of cities, especially in the old weaving town centers. Thus, the ancient texture of many Iranian cities, such as Tehran, Kashan, Yazd, Kerman, Hamedan, Tabriz, from early Pahlavi dynasty onwards, with plans of these experts were washed away and lost its original identity after entering the cars. When included in 5 years Schedule of urban development and urban master plan for Iranian legal provision can be considered from mid 1961-1971. Besides these activities also took a few spread steps have been done:

1. Cleaning the old tissue surrounding the shrine of Imam Reza, the project was done in spite of objection of experts with the old textures before the Islamic republic revolution

2. Cleaning around Charbagh and destroying several valuable buildings around Charbagh up to Naghshe Jahan Square in Isfahan

3. Mitigation plan for the project area Oudlajan Tehran: this project was done for the oldest areas surrounding the market go back to 1987. The original research of these projects was conducted in the years of 1980 to 1981 and after a bomb blast in a corner the context actions stopped.

4. Implementation of more than 700 projects in over 350 building and maintenance of the country's history

5. Criteria for neighborhood renewal project of Julfa, Isfahan, in the year of 1987

6. Jamaleh mitigation plan in the in the old square of Isfahan and so on ( Javadi , 1998 , p 18 ) UK

A major part of the history and civilization of modern Europe is concentrated in the UK in urban Britain. UK is of central European countries, which has rich experiences in renewing (Lari, 1991, p 298).

UK to respond to the needs and problems of older cities that were set up by the industryspecific legislation could eventually cover some of the core issues of the industrial cities of the ancient population so all issues and new needs were taken into consideration and have been answered to them with one vision (Bahraini, 1999)

Several major British policies in improving urban spaces:

1. Protection and maintenance of old and semiold buildings, in isolation but in half the visual and historical value of the building and space in urban

2. Oldest housing renewal policy rather than destructing and renewing

3. Emphasize on aspects of public participation in rehabilitation of old fabric texture

4. Emphasizing on visual, beauty, and cognitive

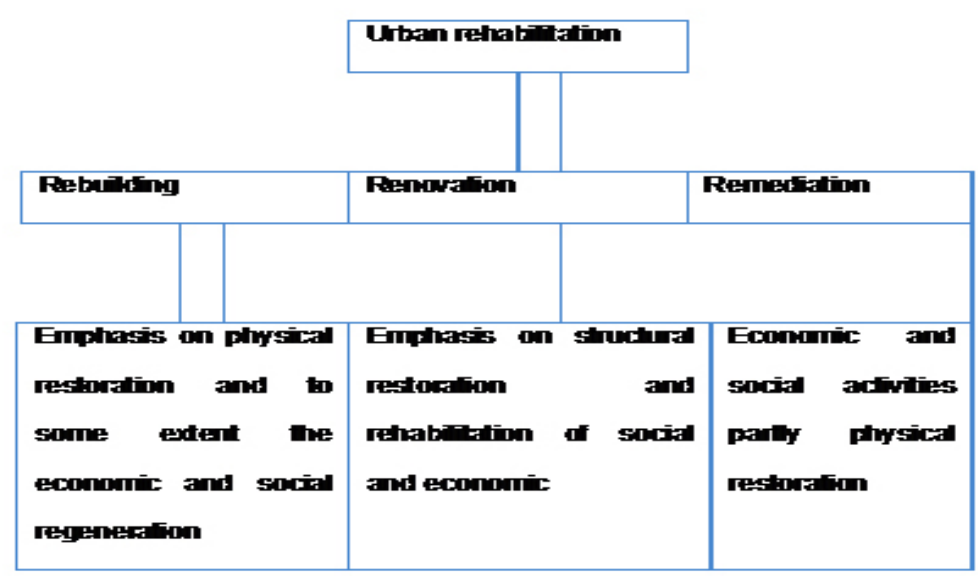

Fig. 1: Strategies for urban rehabilitation (Khaksar, A., Seven Cities, No. 15 and 16, 2004) 
value of the physical environment (Bahraini, 1997; 1998)

5. Of the most important improved cities in England, including the cities of:

\section{Beth purpose}

1. Participation of people or property owner involved in the repair and deformed structure and function

2. increasing municipal revenue through attracting tourists

\section{Chester aims to}

1. Protection of the old structure with the aim of attracting tourists

2. Emphasis on public participation in the rehabilitation of old texture

\section{Chichester aims to}

1. Improving the urban landscape

2. Careful restoration and protection of monuments

3. Damage to buildings without value (Athari, 2001)

\section{Netherlands}

Amsterdam is one of the few cities where the urban and urban planning has been followed consistently (Athari, 2001). In the late of 19 century, development of city and its facilities began in order to overcome to inhabitants needs in big cities. So, efforts began to create urbanization projects in order to create changes in texture. In this city, against London and Paris, rebuilding thrived for low-income and middle-class workers and buildings purchase that were destroyed, it is permissible for urban development programs. And monitoring of all buildings in harmony with the surrounding buildings laid for beautifully commission (Bene, 2003; Lari, 1991, p: 308).

In the case of experiences of rehabilitation and modernization of the Netherlands, following items can be counted:

1. Demolition of dilapidated buildings

2. Improve the quality of life of residents

3. Beautification and decoration of landscape spaces

4. Development of facilities and services equipment in old tissue

5. Adequate parking in non-residential areas (Lari, 1991; Gibbons and Holter, 2001)

\section{Germany}

The old city center of Berlin is Krvzberg. Krvzberg is of parts of downtown Berlin that has quite historic and ancient texture. The texture of the western border of Berlin has been neglected for years.

Due to these shortcomings, guidelines for urban restoration in Spring 2003 was raised by the political committee which aims to find a solution to create favorable conditions for human life in the city and live in harmony between old and new. Because today's needs has changed in comparison to past needs. Krvzberg improvement goals include:

1. To preserve and protect its ancient context

2. Granting loans and subsidies to residents

3. Maintain existing residents

4. Engage the citizens and inhabitants in the rehabilitation and improvement planning so that the method is based on citizen participation (Athari, 2001)

5. Using patterns in Europe, not U.S. cities.

6. A thriving urban center as a place for holding
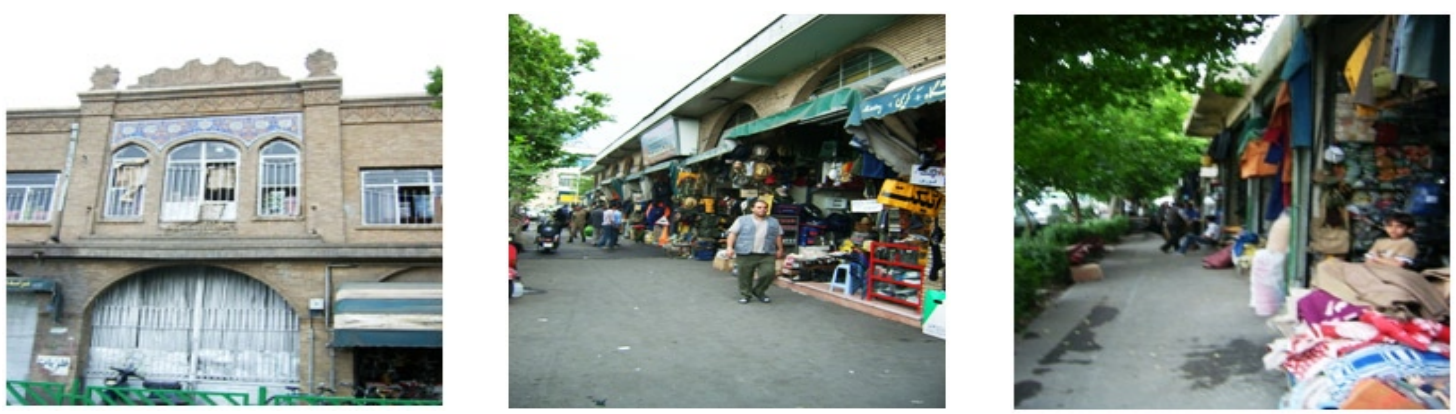

Fig. 2: Street view in area of 11 in Tehran 
a piece of contemporary architecture and commercial activities (Bahraini, 1998, p 68)

\section{Central parts of the city and its range}

The downtown area of convergence of roads and transportation systems are said "solidarity". These roads or streets in the downtown area, change to commercial - services issues and have the highest volume of activity and rashes (Ahmadi, 2004). City center, which is part of the city within a confined space is defined and is a symbolic role. So that essential parts of the city consist of elements and complex issues, and it gives unity and consistency. The city center is the focal point of the downtown scene, the formation and accumulation of the most important urban activities, collective memories and people's presence in the city (Ahmadi, 1997, p 92). Density and business activity in Iran's major cities, in the old tissue of the city and surrounding tissue of Bazar have lead to space occupied by business and residential areas get smaller. Hence, the wholesale and retail stores, production centers, distribution centers and manufacturing goods along with Bazar neiberhood to be developed and old houses of Bazar area have changed to goods barns and production workshops.This process has deteriorated its first identity. City center plays a major role in the city's life. This area represents the highest land values and economic and social transactions, and a member of the same or different functions compared with urban and ultra city (Ahmadi, 2004).

\section{Public participation}

The public participation is purely a cultural concept. In our country public participation in all areas, especially urban management is growing and appearance. In particular, in the present study, public participation plays an important role in improving the urban landscape in either immediate or gradual landscape. Therefore, these are the people who give Soul to lifeless body, make it and will change it.

Today almost "all the experts arena believe on development of participation of group decisionmaking levels and adverse impacts, and determining effective strategies and policies. They emphasize on the role of citizen participation in decision-making. Accordingly, urban managers also plan to increase the probability factor, the legitimacy of a decision, and additional support their actions from the citizens, trying to find strategies and appropriate mechanisms to facilitate this work and examine.
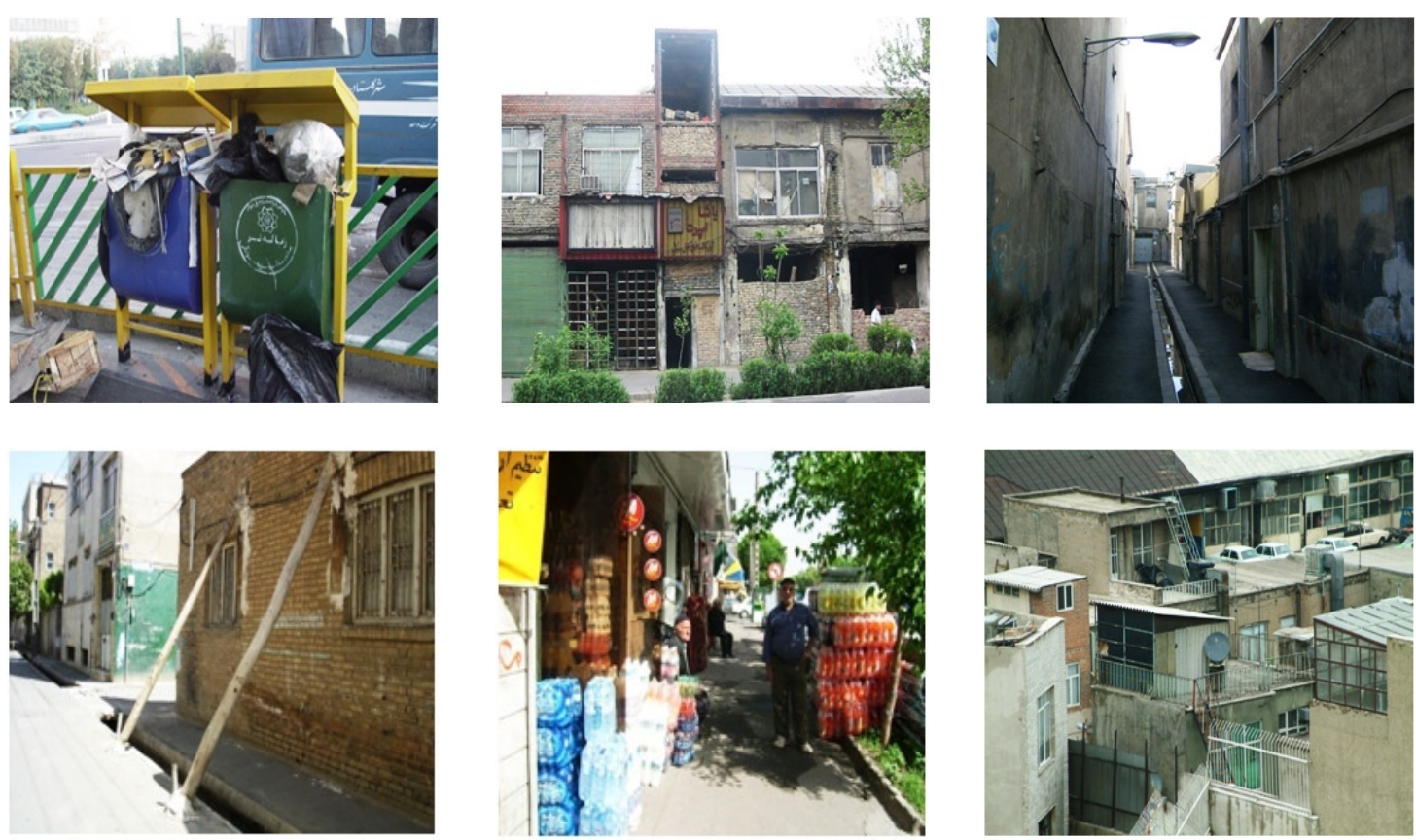

Fig. 3: One of Alley of Mokhtari street with minor width and high walls, old buildings with low autonomy and restoration 
Participation is a selection and a comfortable relationship with the authorities and cooperates with them freely. Participation is a kind of monitoring of individual's and involvement in order to improve it. Examples of barriers to participation include:

1. Limited economic opportunities and low income

2. Recession, market instability and price inflation

3. Being a rental property

4. Administrative issues related to improving financial affairs.

5. Issues of social environment, presence of addicts, vagrant, dealers, crowded place and so on.

6. Historical beliefs of participation

7. Level of education, degree of urbanization, urbanism and civic life

\section{The idea of participatory urban planning}

"Participation is effective involvement of members of a group or community in all activities and decision-making that are related to the whole community" (Pour Ahmed, 1991, p 45). Public participation is a tool that members of a community can participate in policies and projects that effect on their life.

If the citizens of a city participate in policies formulate, plans and programs that prepared to their cities, citizen participation in urban planning has been done.

\section{The emergence of participatory urban planning} ideas

1. The importance of the people in the affairs of society and the emergence and spread of democratic political systems and social

2. Development trends of the past decade reveals that the lack of public participation lead to less development process because it is coming into great losses.

3. Failure to comply with the needs and demands of the urban development plans and programs and the incidence of dissatisfaction and negative reactions toward these projects from the past decades

4. Importance of urban planning and design process

5. Lack of financial ability of governments to

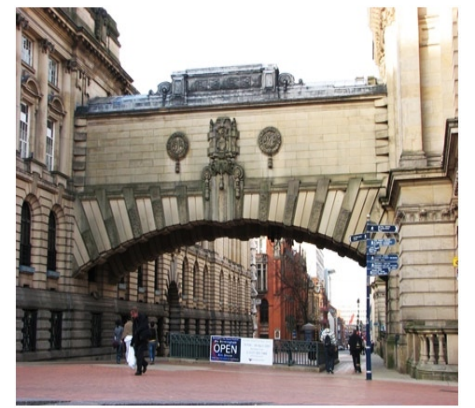

Fig. 4: Pedestrian way, in the context of the central and commercial center of Birmingham city, which is a shortcut way for accessing the central tissue.

finance urban development projects

6. felt threatened to citizens

Patterns of citizen paricipation in urban governance in some countries iran

In Iran, participation is involved in both traditional and new forms. Traditional forms has existed for a long time, and considering that developments in last hundred years, has continued strength in some of the cities in Iran. New participation is a kind of participation that government use it for its special goals and with organizations try to attract citizens participation in fields that had not historical activities in social life before. In order to be familiar with historical examples of traditional participation in urban governance and new partnerships can include:

1. Due to the importance of religion, it had caused people to restore and to build temples so that you could see that in the book of Pigolosca, by the name of Iranian cities in the Parthian and the Sassanid that has mentioned about public participation in the building of temples.

2. After the invasion of Alexander of Macedon and the Seleucid kingdom some of the customs and traditions of Greek life was introduced to the life of Iranians. Among them was the way the town's police department. For example, the city of Seleucia ran by the Senate, where three hundred people were selected based on wealth and wisdom.

3. Seleucia Kings avoided direct involvement in urban affairs and urban affairs were managed by the City Council. 
4. In Iran, an example of a life based on citizen participation is in tribal life. Among tribals, rooted traditional partnerships are existed that is based on the life of society.

5. The most efficient and partnerships production methods among farmers were foundations. Foundations are latent organizations, cooperatives, related to traditional production of agricultural products of Iran. One reason for its creation can be seen as the geographical conditions of water scarcity (Ahsan, 1994, pp. 53 and 54).

\section{United states}

United States is comprised of fifty-five states, which each have autonomy in their internal affairs. The federal government is interfere only constitutional affairs, national security, to maintain their connectivity, and in cases that have not ability to overcome on them. In the American Management Systems, councils are obvious manifestation of citizen participation in urban management, and have particular importance. In U.S. has been tried that citizen participation in decision-making and urban planning is not only limited to review. However, all individuals, particularly low-income social groups could have been involved in this field. One of the most notable programs in urban planning that tries to make it out of the official dealer of the group is the tnt programs. The residents guide the name stands for one of the neighborhoods of the English master plan planning. This program to maintain low-income neighborhoods in the field of perspectives for the future and development of skills, communication and policies to work together and to turn those ideas into reality (Ahsan, 1994, p 104).

\section{Sweden}

Sweden is among the countries and is governed with long democratic methods based on public participation. In Sweden, for the implementation of local autonomy, municipalities exist. Regional autonomy is the State Council. The state constitution in the section of governing rules sets that has in the interpretation of the most important rules of three basic principles, express the principles of governing the affairs of this method. In Swedish municipalities, the highest authority is City Council. In addition, in the level of provincial, makes decisions. Of the tools in Stockholm that are used to increase, public participation in municipal affairs could note to the right of citizens to participate in all meetings of the City Council. This time of the meetings that is convened twice a month would be announced through the newspapers. On the other hand, in Sweden to encourage citizen participation in municipal affairs, especially in special section of municipal services, urban local bodies are made up of specific tasks. Local institutions that the City Council shall appoint its members can complete them and sometimes municipal management committees (Carl Kenotsen, 1991, p 33) can replace it.

\section{France}

In France, municipal urban management system have an important and significant role in other areas related to decision making and the preparation and implementation of urban management in this country. Having a look at different steps of a project shows that from first step, consult step, with organizations and associations are based on citizens' participation. Another steps including distributing the projects, consult with organization and associations and finally approved plan, demonstrate the importance of public participation in the preparation of this plan (Pour Ahmed, 1991). One of the significant programs in France municipalities is the importance that is given to younger generation. For example, in the city of Plan in the suburbs of Paris, every year during the celebration, one of the young people between 14 to 20 years is elected for one day as the city mayor in 28 December every year. This young is selected by election and is very competent to do the job of a mayor. It is a condition that the person elected as mayor of a municipality must be familiar with the duties and responsibilities of a mayor and usually open facility is of young mayor responsibility (Ahsan, 1994, p 118; Hull, 2003). One of the laws in force in France is a law called "solidarity and urban modernization" that has been approved in 2000 . This law has created many changes in municipal law. Great emphasis of this law is on public participation in urban management. Due to numerous economic and social problems that have recently been made in the French, different methods are tested in response to them. Among them, participatory methods have witnessed the success (Athari, 2001, p 20). 


\section{United kingdom}

In England, protection and maintenance of existing buildings that have architectural value, has a long history and dates back to the 19th century. First action had cultural aspect and of the people, themselves. In 1877, William Morris founded the Society of conservation of historic buildings that still stands. Keeping the idea of building laws was along with new laws and gradually evolved to sustain, reform and new laws. So that, it changed from attention and emphasis to preservation and renewal of individual buildings in urban areas. Especially, it can be mentioned to urban interoperability and harmony that in 1967, had especial emphasizes on urban values and protection. After decades till now, the issue of public participation in the process of improving urban spaces in the historical part of the city has expanded and filled and always has encountered with lots of issues and guidelines (Bahraini, 1998, p 62).

\section{Failure and evils of landscape view}

Failures and evils are opposite the aesthetic standards. Briefly, the ugly face of the city is dirty and degraded state of many old buildings. This is especially, in areas with powerful business users, especially on the ground floor. Such areas are streets like Enqelab-E-Eslami, Jomhoori Eslami, Hafez, south of Valiasr Street, Arg, Razi square, Rah-Ahan square, Shush, Molavi and Helale Ahmar streets in district 4 of the area. From the aspects of the dirtiness and pollution of streams and rivers parties with atmospheric passages that are in place for domestic wastewater discharge are very ugly effects of area feature. Establishment of garage and other shops in the streets of Kargar, Qazvin, Molavi, Helale Ahmar and so on, usually put ugly landscape and unpleasant view for people. Spotted making particularly true pavements are clear examples of the ugly appearance of the area (Fig 2).

Chaharsou Choobi under passing, with the function of neighborhood center, due to the lack of sufficient outreach and monitoring, and due to the richness of architectural and historical value have good prospect. Further, if the size and composition of the structural mass of buildings confining are in a way that surface streets looks relevant bodies, it is said that there is a unity of form synchronized views (Fig 3). Urban landscape of the study area has anomalous situation and of the reasons for that can be outlined:

1. Lack of visual spatial values

2. Rash and intensity of traffic

3. Renovation and construction criteria of changes

4. Incompatibility between space and weaknesses of working

5. Structural compression of surrounding city blocks

6. Severe air pollution in street

7. Business activity and passage blocked because of that

8. Environmental pollution caused by hygiene residents

\section{Major obstacles against successful application and practice in physical space}

Failure mode mainly is because of the communal spaces of such spaces in the formation of spatial structures in Tehran, which spontaneously and during different time steps and with no programming is all discrimination. Therefore, because there is no predetermined schedule for these spaces, major problems in terms of physical and spatial are existed. This particular problem can be analyzed from two perspectives and physical planning. In the context of contemporary urban planning must be acknowledged that any attempt to create urban spaces in major cities in Iran have not done, even yet. Texture of the old and central cities of most Iranian cities are of complete contents of this example.

Unfortunately, the urban spaces that have left from past century in recent decades have gradually undergone degradation and physical environment (e.g., spatial and structural changes undertaken in Toopkhane square). In examining the causes and continuation of such trends in contemporary urbanization, diverse and abundant issues have been raised. It seems that one of the reasons is because of entrance of modernism and its effects on Tehran at the late of Qajar govern and its continuity in Pahlavi governs. This is reason that despite the physical expansion of the 11 area mostly occurred in late of Qajar and early Pahlavi, but there is no special collective and urban space in the area and the collective spaces are mostly without special planning and have formed gradually. 


\section{CONCLUSION}

Depreciation arises from poor equipment and furniture of the urban, environmental pollution, and many other details in the context of disorganized urban mainly caused by the central cities have led to face with series of uncoord inated urban landscape. The necessity of immediate planning for responsible is required. This research focuses on identifying the challenges facing for organizing the urban landscape, and shows that firstly, range of components and components that need to organize the urban landscape are much broader than physical dimensions. Second, it is emphasized that the actual organization of urban landscape depends on quality control procedures of designed structures from respective organizations, and changes in laws and administrative regulations, monitoring and changes in government's attitude to the tissues of the urban in bad conditions. Furthermore, despite the substantial challenges, culture and education with the provision of suitable facilities for relaxation on one hand, and the organization of space and improve the spaces facilities, creating the collective memory and creating the public meetings interaction It would increase public participation in improving morale.

\section{Suggestions}

1. Develop a comprehensive plan for the organization of Tehran, with view and Urban Landscape and to develop the rules and regulations for renewing the building and how to monitor it.

2. Inspection of serious attention to the third principle of the building facade and monitor them thoroughly in harmony with the surrounding buildings.

3. To develop cooperative and private sectors for technical principles of construction and especially designing and features implementations related to the Islamic-Iranian rich history architecture, and encourage good models to consider concessions.

4. Revision of laws and regulations relating to renewing and landscape beautification developed by the Municipality of Tehran and requiring contractors to these principles through effective monitoring by the municipalities.

5. Creating green and small spaces and development culture by providing free of charge resources such as plants, shrubs and pots and regulate it to give a better view and appearance in old texture in urban landscape.

6. Optimal restoration of the building with architectural value as an aesthetic factor and destruction of old buildings, rather than a coat of paint. Today's, in Tehran, especially in old textures we could see old buildings and sometimes with architectural value that have been covered with thin layer different colors e.g. yellow, brown and so on. These paintings are not effective and useful for visual quality and will be destructed over time. Urban management with planning and implementation tools can order property owners to make improvements and repairs the old buildings. And, in this way an effective step will improve the visual quality of landscape by encouraging facilities by citizen participation in urban management.

7. According to this fact that, feature of good governance, is sustainable development and foster the participation of the people. Establishment of more participation of citizens in the affairs of the city, using the experiences of other countries is essential. In the city of Paris every year, one young that has enough knowledge about urban is elected as a mayor and small projects in the same day, inaugurated by this young mayor.

8. Urban management with an integrated program of education can improve citizen' participation in effective landscape, ciew, and improving their lives.

9. Identification of alternate routes and shortcuts (which are often a neighborhood of shopping centers with commercial users) within the context of central and busy area into pedestrian ways (Fig 4) 


\section{REFERENCES}

1. Ahmadi, H. An approach to urban planning in the world, third part, USA, Tehran, center of studies and Planning Ministry of Interior. (1997).

2. Ahmadi, H. A view on the programming model in the world, Tehran, Urban Planning Center Press. (2004).

3. Ahmadi, H. Urban planning, public participation. Municipalities Journal (in Persian), 36: 18, (1997).

4. Ahsan, M. Focusing and un-centralize and its physical affects, Abadi Journal (in Persian), 15(4), 22-34, (1994).

5. Astrvfsky, V. Urban Contemporary, translated by E’tezadi L, Tehran University Publication, (1992).

6. Athari, J. Municipal Partnership policies in metropolitan France. Municipalities Journal (in Persian), 37, 20, (2001).

7. Bahraini, H. Analysis of urban spaces, Tehran, Tehran University, (1997).

8. Bahraini, H. Urban planning process, Tehran, Tehran University Press. (1998).

9. Bahraini, M. Environmental Modernism and then urbanization, Tehran, Tehran University Press. (1999).

10. Bene Volvo, L. The Origins of Modern Town Planning, Translated by Katebi M, Tehran, University of Science and Technology.
(2003).

11. Carl Kenotsen. Local self-government in Sweden, translated by Qadyr motamedi, Abadi Journal, first volume, second edition. (1991).

12. Hull, P. Translated by Kamal Tabrizi. Urban and Regional Planning, Tehran, publication of processing and urban planning. (2003).

13. John, L., Matlak. 'Familiarity with the environment and landscape design, Volume I, translated by the Education Department of Parks and green spaces of Tehran, Tehran, Tehran, publications, organizations, parks and green spaces. (2003).

14. Gibbons, J., Holter, F. Landscape design of urban streets, Translation by deputy of education, and training of parks and green spaces. (2001).

15. Lari, K. Principles of optimal design of public spaces in cities, Journal of Research, Training and Information of municipalities, 30 November. (1991).

16. Pour Ahmad, A. Geography and building the city of Kerman, Tehran, Tehran University, Jahad Publications Office. (1991).

17. Quinn, L. Urban landscape, translated by Manouchehr Mazini, Tehran, Tehran University Press. (2003). 